\title{
PENGARUH PENGGUNAAN MEDIA PEMBELAJARAN BERBASIS KOMPUTER DAN KEMAMPUAN BERPIKIR KREATAIF TERHADAP HASIL BELAJAR BAHASA INDONESIA
}

\author{
Iskandar Lubis \\ Guru SD Islam Al Ulum Terpadu Medan, Sumatera Utara \\ aitamaharani@gmail.com
}

\begin{abstract}
Abstrak: Penelitian ini bertujuan untuk mengetahui : perbedaan hasil belajar Bahasa Indonesia siswa yang menggunakan media pembelajaran interaktif ispring suite dibandingkan dengan yang menggunakan media pembelajaran microsoft office power point, mengetahui perbedaan hasil belajar Bahasa Indonesia siswa yang memiliki kemampuan berpikir kreatif tinggi dibandingkan dengan yang memiliki kemampuan berpikir kreatif rendah, dan interaksi antara media pembelajaran berbasis komputer dan kemampuan berpikir kreatif dalam memengaruhi hasil belajar Bahasa Indonesia. Metode penelitian quasi eksperimen, populasi 30 orang, teknik pengambilan sampel menggunakan purposive sampling, analisis varians dua jalur Two Way Anava (2x2), taraf signifikansi $\alpha=0,05$, menggunakan uji-F, dan pengujian uji lanjut dengan uji Scheffei. Hasil penelitian diperoleh; hasil belajar Bahasa Indonesia siswa yang dibelajarkan dengan media interaktif iSpring Suite lebih tinggi dibandingkan dengan siswa yang dibelajarkan dengan media microsoft office power point 2013, siswa yang memiliki kemampuan berpikir kreatif tinggi memeroleh hasil belajar Bahasa Indonesia yang lebih tinggi dibandingkan dengan siswa yang memiliki kemampuan berpikir kreatif rendah, dan terdapat interaksi antara media pembelajaran berbasis komputer dan kemampuan berpikir kreatif dalam memengaruhi hasil belajar Bahasa Indonesia.
\end{abstract}

Kata Kunci: Media Pembelajaran Berbasis Komputer, Berpikir Kreatif, Hasil Belajar, Bahasa Indonesia.

\begin{abstract}
Abstract: This study aims to determine: differences in learning outcomes Indonesian students who use interactive learning media iSpring suite compared with the use of instructional media microsoft office power point, determine differences in learning outcomes of Indonesian students who have the creative thinking ability higher than the one having creative thinking ability is low, and the interaction between the computer-based learning media and creative thinking abilities in influencing learning outcomes Indonesian. Quasi-experimental research methods, a population of 30 people, the sampling technique used purposive sampling, analysis of variance of two lines Two Way Anova (2x2), the significance level $\alpha=0.05$, using the F-test, and testing of advanced test by test Scheffei. The results were obtained; learning outcomes Indonesian students that learned with interactive media iSpring Suite is higher than students that learned with media microsoft office power point 2013, students who have the ability to think creatively height attained learning outcomes Indonesian higher compared with students who have the ability to think creatively low, and there is interaction between computer-based learning media and creative thinking abilities in influencing learning outcomes Indonesian.
\end{abstract}

Keywords: Computer-Based Learning Media, Creative Thinking, Learning Outcomes, Indonesian Language

\section{PENDAHULUAN}

Salah satu masalah pembelajaran Bahasa Indonesia di sekolah adalah rendahnya penguasaan 4 keterampilan berbahasa, khususnya kemampuan mendengarkan dan membaca. Seperti diungkapkan oleh Hanafiah dan Suhana (2010:2), rerata hasil tes kemampuan membaca siswa SD dan SMP di beberapa negara yang dilakukan oleh World Bank 1998, menunjukkan, Hongkong 75,5\%, Singapura $74 \%$, Thailand $65 \%$, Filipina dan Indonesia $51,7 \%$. Siswa Indonesia jenjang kelas IV SD hanya mampu mengerjakan 34\% soal dan SMP mampu mengerjakan 52\% soal. 
Mereka hanya mampu memahami 30\% dari materi bacaan dan mengalami kesulitan menjawab soal-soal berbentuk uraian yang memerlukan penalaran sehingga berada pada peringkat paling bawah. Banyak faktor di dalam pembelajaran yang menyebabkan rendahnya hasil belajar Bahasa Indonesia, seperti fenomena tersebut. Satu di antaranya adalah masih sedikitnya penggunaan media pembelajaran di dalam proses pembelajaran.

Kemampuan berbahasa merupakan hal yang utama, seperti diungkapkan Suriasumantri (2005:171), "Keunikan manusia sebenarnya bukanlah terletak pada kemampuan berpikirnya melainkan terletak pada kemampuan berbahasa. Manusia dapat berpikir dengan baik karena dia mempunyai bahasa. Tanpa bahasa, manusia tidak dapat mengomunikasikan pengetahuan kepada orang lain."

Untuk membantu tersampaikannya pesan dengan benar kepada komunikan diperlukan saluran berupa media pembelajaran. Efisiensi dan efektivitas proses dan hasil pembelajaran dapat dicapai dengan memanfaatkan media pembelajaran secara optimal. Proses pembelajaran tanpa dukungan pemakaian media yang tepat membutuhkan waktu lebih panjang dalam menyampaikan pesan kepada peserta didik. Bahkan, adakalanya peserta didik tidak dapat memahami pesan yang diterimanya secara tepat seperti yang diinginkan oleh si penyampai pesan. Sebaliknya, proses pembelajaran tersebut dapat dioptimalkan dengan menggunakan media pembelajaran yang tepat. Konsekuensinya, pencapaian hasil belajar juga lebih baik.

Penggunaan media pembelajaran berbasis komputer: media pembelajaran interaktif iSpring Suite dan Microsoft Office Power Point 2013 dalam pembelajaran, khususnya pembelajaran Bahasa Indonesia pada kompetensi dasar menanggapi penjelasan narasumber dengan memerhatikan santun berbahasa; mengidentifikasi unsur cerita rakyat yang didengarnya; dan menemukan gagasan utama suatu teks yang dibaca belum pernah dilakukan oleh guru. Padahal, selain mudah dalam pembuatannya, media pembelajaran berbasis komputer, khususnya media pembelajaran interaktif iSpring Suite dapat dilengkapi dengan animasi, audio, dan video yang mampu menarik perhatian sehingga lebih memotivasi siswa dalam pembelajaran. Karkateristik belajar siswa sekolah dasar yang lebih dekat dengan dunia bermain dapat diakomodasi melalui perancangan kuis menarik dan interaktif di dalam pembelajaran dengan media iSpring Suite. Selain itu, media interaktif iSpring Suite ini dapat diintegrasikan dengan microsoft lainnya, seperti word dan excel sehingga pemanfaatannya dapat lebih diperkaya. Media pembelajaran interaktif iSpring Suite dapat pula dirancang sedemikian rupa sehinggga bersifat multimedia, yaitu dengan menggabungkan berbagai unsur media, seperti teks, gambar, animasi, dan video (Susilana Rudi dan Cepi Riyana, 2009).

Diasumsikan bahwa pembelajaran dengan menggunakan media pembelajaran berbasis komputer: media pembelajaran interaktif iSpring Suite dan Microsoft Office Power Point 2013 dapat meningkatkan kualitas proses dan hasil belajar Bahasa Indonesia. Oleh karena itu, dibutuhkan sebuah penelitian tentang pengaruh penggunaan media pembelajaran berbasis komputer: iSpring Suite dan Microsoft Office Power Point 2013 dan kemampuan berpikir kreatif terhadap hasil belajar Bahasa Indonesia. Dengan melakukan penelitian akan diperoleh suatu formula pembelajaran Bahasa Indonesia yang lebih baik dan mampu menginspirasi peserta didik menjadi insan yang memiliki kemampuan berbahasa Indonesia baik lisan maupun tulis lebih baik.

Kemampuan seseorang dalam memperkirakan dan menyimpulkan pemecahan masalah dengan mengoptimalkan kemampuan berpikir imajinatif sehingga memproduksi solusi yang bersifat baru, asli/orisinal, cerdik, dan mengagumkan itulah yang disebut dengan kemampuan berpikir kreatif (creative thinking) Sumiati dan Asra (2009:137). Jadi, seseorang yang memiliki kemampuan berpikir kreatif haruslah mampu mengeksplorasi terhadap area, melakukan pengamatan baru, perkiraan (prediksi) baru dan simpulan baru, (Skinner dalam Sumiati dan Asra, 2009:137).

Penelitian ini merupakan upaya untuk mengetahui apakah media pembelajaran berbasis komputer, yakni media pembelajaran iSpring Suite dan Microsoft Office Power Point 2013 dan kemampuan berpikir kreatif siswa dapat memengaruhi hasil belajar. Driscoll dalam Smaldino, dkk (2011:11) menyatakan bahwa belajar (learning) sebagai perubahan terus-menerus dalam kemampuan yang berasal dari pengalaman pemelajar dan interaksi pemelajar dengan dunia. Belajar merupakan 
pengembangan pengetahuan, keterampilan, atau sikap yang baru ketika seseorang berinteraksi dengan informasi dan lingkungan. Lingkungan belajar diarahkan oleh guru dan mencakup fasilitas fisik, suasana akademik dan emosional, serta teknologi pengajaran (Smaldino, dkk, 2011:11).

Djamarah (2008:13) menyimpulkan, belajar adalah serangkaian kegiatan jiwa dan raga untuk memeroleh suatu perubahan tingkah laku sebagai hasil dari pengalaman individu dalam interkasi dengan lingkungannya yang menyangkut kognitif, afektif, dan psikomotor.

Slameto (2010:2) menyatakan, belajar ialah suatu proses usaha yang dilakukan seseorang untuk memperoleh suatu perubahan tingkah laku yang baru secara keseluruhan, sebagai hasil pengalamannya sendiri dalam interaksi dengan lingkungannya. Sementara itu Sanjaya (2010:112) berpendapat, belajar bukanlah sekadar mengumpulkan pengetahuan. Belajar adalah proses mental yang terjadi dalam diri seseorang sehingga menyebabkan munculnya perubahan perilaku. Aktivitas mental itu terjadi karena adanya interaksi individu dengan lingkungan yang disadari. Belajar adalah proses berpikir yang menekankan kepada proses mencari dan menemukan pengetahuan melalui interaksi antara individu dan lingkungan (Sanjaya, 2010:107).

Bukti bahwa seseorang telah belajar adalah terjadinya perubahan tingkah laku pada orang tersebut, misalnya dari tidak tahu menjadi tahu, dan dari tidak mengerti menjadi mengerti. Belajar pada hakikatnya adalah suatu aktivitas yang mengharapkan perubahan tingkah laku (behavioral change) pada individu yang bersangkutan. Menurut Tyler dalam Anderson dan Krathwohl (2010:20) perubahan tingkah laku atau yang disebutnya sebagai perilaku itu merupakan hasil belajar. Hasil belajar ditentukan oleh tujuan pembelajaran yang dirumuskan. Sementara itu, aktivitasaktivitas pembelajaran merupakan cara untuk mencapai tujuan pembelajaran tersebut.

Anderson dan Krathwohl (2010:95), mengungkapkan bahwa ada tiga hasil belajar ditilik dari aktivitas belajar, yaitu (1) hasil belajar nol atau tidak ada hasil belajar karena pada dasarnya siswa tidak belajar; (2) hasil belajar menghafal apabila siswa memiliki pengetahuan yang relevan, tetapi tidak dapat menggunakannya dalam pemecahan masalah. Siswa tidak dapat mentransfer pengetahuannya ke dalam situasi yang baru. Hal itu disebabkan karena siswa hanya menyimak informasi dan tidak memahaminya; (3) hasil belajar bermakna dapat berlangsung pada diri siswa apabila mereka selain memiliki pengetahuan relevan, memahaminya, juga dapat menggunakannya dalam menyelesaikan masalah dan memahami konsep-konsep baru. Siswa dapat mentrasfer pengetahuannya pada masalah dan situasi yang baru.

Ada empat keterampilan berbahasa yang saling mendukung dan melengkapi, yaitu (1) keterampilan menyimak, (2) keterampilan berbicara, (3) keterampilan membaca, dan (4) keterampilan menulis. Keterampilan menyimak memegang peranan penting, baik di dalam proses pembelajaran maupun di dalam kehidupan sehari-hari. Keterampilan menyimak berpengaruh secara langsung terhadap ketiga keterampilan berbahasa lainnya. Dengan demikian, kemampuan menyimak pun secara langsung akan memengaruhi hasil belajar yang diperoleh siswa. Menyimak adalah mendengarkan (memerhatikan) baik-baik apa yang diucapkan atau dibaca orang (KBBI, 2000:1066). Sesuai dengan definisi tersebut, keterampilan menyimak disebut pula dengan keterampilan mendengarkan. Dengan kata lain menyimak sama dengan mendengarkan.

Membaca adalah suatu proses yang dilakukan serta dipergunakan oleh pembaca untuk memperoleh pesan, yang hendak disampaikan oleh penulis melalui media katakata/ bahasa tulis, (Tarigan, 1990:7). Depdiknas (2008:9-13) mengungkapkan ada 5 jenis membaca, yaitu (1) membaca permulaan, (2) membaca dalam hati, (3) membaca cepat, (4) membaca teknik, dan (5) membaca kreatif.

Smaldino, dkk. (2011:7) menjelaskan bahwa media merupakan alat komunikasi dan sumber informasi. Kata media yang berasal dari bahasa Latin mengarah kepada segala sesuatu yang membawa informasi dari suatu sumber kepada penerimanya. Lebih lanjut beliau mengemukakan enam tipe dasar media, yaitu (1) teks, yang dapat disajikan dalam berbagai format seperti buku, poster, papan tulis, layar komputer, dan sebagainya, (2) audio, termasuk di dalamnya segala sesuatu yang dapat didengar seperti suara manusia, musik, suara mekanis, dan sebagainya, (3) visual, termasuk diagram dalam poster, gambar di papan tulis putih, foto, gambar di buku, kartun, dan sebagainya, (4) video, termasuk DVD, rekaman video,animasi komputer, dan 
sebagainya, (5) model (perekayasa tiga dimensi, bisa disentuh dan dipegang) dan benda sebenarnya, dan (6) orang-orang, bisa berupa guru, siswa, atau ahli bidang studi.

Media pembelajaran berbasis komputer biasanya berupa software komputer berupa program komputer yang di dalamnya berisi tentang muatan pembelajaran, mencakup: judul, tujuan, materi, dan evaluasi pembelajaran. seperti dikemukakan oleh Heinich dan Russel dalam Rusman (2011:97), "Computer system can delivary instructon by allowing them to interact with the lesson programmed into the system; thisi refered to computer based instruction." Sistem komputer dapat menyampaikan pembelajaran secara individual dan langsung kepada para siswa dengan cara berinteraksi dengan mata pelajaran yang diprogramkan ke dalam sistem komputer, inilah yang disebut dengan pembelajaran berbasis komputer. Pembelajaran berbasis komputer sudah mencakup di dalamnya media pembelajaran berbasis komputer.

Microsoft Office Power Point 2013 merupakan bagian dari Microsoft Office 2013 yang merupakan seri paling baru dari Microsoft Office Productivity Suite dan Microsoft Windows. Versi ini merupakan versi lanjutan dari versi Microsoft Office 2010. Microsoft Office 2013 mencakup dukungan ekstensi file yang diperlukan, halaman muka yang diperbarui dan mendukung sentuhan untuk teknologi layar sentuh. Microsoft Office 2013 sangat cocok bagi komputer dengan prosesor yang berarsitektur Intel 32 bit dan 64 bit. Sistem operasi Windows yang mendukung Microsoft Office 2013 adalah Windows 7, Windows Server 2008 R2, dan Windows 8. Microsoft merilis Office 2013 kepada publik pada 28 Januari 2013.

Munandar dalam Asrori (2009:62)) mendefinisikan bahwa kreativitas adalah kemampuan yang mencerminkan kelancaran, keluwesan, dan orisinalitas dalam berpikir serta kemampuan mengelaborasi suatu gagasan yang merupakan hasil interaksi dengan lingkungannya. Lingkungan tidak hanya mampu mendukung berkembangnya kreativitas, tetapi justru dapat pula menghambat perkembangan kreativitas pada diri seseorang.

Talajan (2012:11) mengungkapkan, secara umum kreativitas dapat diartikan sebagai pola berpikir atau ide yang timbul secara spontan dan imajinatif, yang mencirikan hasil artistik, penemuan ilmiah, dan penciptaan secara mekanik. Kreativitas meliputi hasil sesuatu yang baru, baik sama sekali baru bagi dunia ilmiah atau budaya maupun secara relatif baru bagi individunya sendiri walaupun mungkin orang lain telah menemukan atau memproduksi sebelumnya.

Berdasarkan beberapa pendapat pakar tentang kreativitas, Asrori (2009:62-63) mengidentifikasi bahwa definisi-definisi tersebut mengacu pada 4 kategori, disingkat dengan istilah 4P, yaitu : (1) produk atau hasil-hasil karya kreatif, baik yang sama sekali baru dan belum pernah ada sebelumnya maupun kombinasi atau modifikasi karya-karya terdahulu sehingga menghasilkan sesuatu yang baru; (2) personal atau orang-orang yang memiliki kepribadian atau pemikiran kreatif dapat dilihat dari tindakan atau perilaku kreatif yang tampak nyata; (3) proses kreatif yang berlangsung sejak dari mulai tumbuh akibat interaksi individu dengan lingkungannya sampai berwujud perilaku kreatif - di dalamnya berlangsung proses inkubasi "pengeraman" ide/ gagasan; (4) press yaitu penekanan pada faktor-faktor yang mendukung bahkan menghambat munculnya kreativitas pada diri seseorang. Hal yang senada diungkapkan oleh Talajan (2012:11), definisidefinisi kreativitas dapat dibedakan ke dalam dimensi individu atau personal, proses, produk, dan publikasi. Rhodes dalam Talajan (2012:11) menyebut empat dimensi kreativitas tersebut dengan the Four P'S of Creativity.

Rumusan masalah pada penelitian ini adalah: (1) Apakah terdapat perbedaan hasil belajar Bahasa Indonesia siswa yang menggunakan media pembelajaran interaktif iSpring Suite dibandingkan dengan yang menggunakan media pembelajaran Microsoft Office Power Point 2013?, (2) Apakah terdapat perbedaan hasil belajar Bahasa Indonesia siswa yang memiliki kemampuan berpikir kreatif tinggi dibandingkan dengan yang memiliki kemampuan berpikir kreatif rendah?, dan (3) Apakah terdapat interaksi antara penggunaan media pembelajaran berbasis komputer dan kemampuan berpikir kreatif dalam memengaruhi hasil belajar Bahasa Indonesia?

\section{METODE}

Populasi dalam penelitian ini adalah seluruh siswa kelas V SD Islam Al Ulum Terpadu Medan yang terdiri atas 2 (dua) kelas, yakni kelas VA berjumlah 30 siswa dan VB yang berjumlah 30 siswa. eknik pengambilan 
sampel pada penelitian ini adalah dengan menggunakan teknik purposive sampling dengan melakukan penelitian terhadap seluruh populasi yang ada.

Desain penelitian ini menggunakan pendekatan eksperimen yang merupakan penelitian yang berusaha mencari dan menguji pengaruh satu variabel atau lebih terhadap variabel yang lain.Penelitian ini bersifat Quasi Experiment (eksperimen semu) dengan desain faktorial 2x2. Dengan desain ini akan dibandingkan pengaruh media pembelajaran interaktif iSpring Suite dan media pembelajaran microsoft office power point 2013 terhadap hasil belajar Bahasa Indonesia ditinjau dari kemampuan berpikir kreatif. Media pembelajaran interaktif iSpring Suite dan microsoft office power point 2013 diperlakukan pada kelompok eksperimen siswa dengan kemampuan berpikir kreatif tinggi dan rendah.

Media pembelajaran interaktif iSpring Suite dan microsoft office power point 2013 diperlakukan pada kelompok eksperimen siswa dengan kemampuan berpikir kreatif tinggi dan rendah yang dijelaskan pada Tabel 1 berikut ini.

Tabel 1. Desain Penelitian Faktorial 2 x 2

\begin{tabular}{|c|c|c|}
\hline Media Pembelajaran & iSpring Suite & $\begin{array}{c}\text { Microsoft office } \\
\text { power point } 2013\end{array}$ \\
\hline $\begin{array}{l}\text { Kemampuan } \\
\text { Berpikir Kreatif }\end{array}$ & $\left(\mathrm{A}_{1}\right)$ & $\left(\mathrm{A}_{2}\right)$ \\
\hline Tinggi $\left(\mathrm{B}_{1}\right)$ & $\mathrm{A}_{1} \mathrm{~B}_{1}$ & $\mathrm{~A}_{2} \mathrm{~B}_{1}$ \\
\hline Rendah $\left(\mathrm{B}_{2}\right)$ & $\mathrm{A}_{1} \mathrm{~B}_{2}$ & $\mathrm{~A}_{2} \mathrm{~B}_{2}$ \\
\hline
\end{tabular}

Teknik pengumpulan data pada penelitian ini adalah dengan menggunakan teknik tes berupa tes objektif bentuk pilihan ganda dan essay. Teknik tes pilihan ganda digunakan untuk mengumpulkan data hasil belajar Bahasa Indonesia, sedangkan teknik tes essay digunakan untuk mengumpulkan data tentang kemampuan berpikir kreatif siswa.

Teknik analisis yang dilakukan pada penelitian ini adalah dengan analisis deskriptif kuantitatif dan analisis inferensial. Analisis deskriptif kuantitatif digunakan untuk menganalisis data dengan cara mendeskripsikan atau menggambarkan data yang telah terkumpul. Berdasarkan data dan daftar frekuensi tersebut dihitung nilai rata-rata, simpangan baku, median, dan modusnya. Sedangkan, analisis inferensial dilakukan dengan teknik Anava faktorial 2 × 2 dengan uji F. Sebelum hipotesis diuji terlebih dahulu dilakukan uji persyaratan terhadap data yang dikumpulkan yaitu melakukan uji normalitas dengan menggunakan uji Liliefors dan uji homogenitas dengan menggunakan uji $\mathrm{F}$ dan uji Bartlett. Jika hipotesis ketiga dinyatakan signifikan artinya terdapat interaksi, uji penelitian dilanjutkan dengan menggunakan uji Scheffe. Pengujian penelitian dengan uji Scheffe dilakukan karena jumlah data setiap sel berbeda.

Adapun hipotesis statistik yang akan diuji dengan uji ANAVA, sebagai berikut.

a. Hipotesis pertama :

$$
\begin{aligned}
& \mathrm{H}_{\mathrm{o}}: \mu \mathrm{A}_{1} \leq \mu \mathrm{A}_{2} \\
& \mathrm{H}_{\mathrm{a}}: \mu \mathrm{A}_{1} \geq \mu \mathrm{A}_{2}
\end{aligned}
$$

b. Hipotesis kedua :

$$
\begin{aligned}
& \mathrm{H}_{\mathrm{o}}: \mu \mathrm{B}_{1} \leq \mu \mathrm{B}_{2} \\
& \mathrm{H}_{\mathrm{a}}: \mu \mathrm{B}_{1} \geq \mu \mathrm{B}_{2}
\end{aligned}
$$

c. Hipotesis ketiga :

$$
\begin{gathered}
\mathrm{H}_{\mathrm{o}}: \text { Interaksi } \mu \mathrm{A}><\mu \mathrm{B}=0 \\
\mathrm{H}_{\mathrm{a}}: \text { Interaksi } \mu \mathrm{A}><\mu \mathrm{B} \neq 0
\end{gathered}
$$

\section{HASIL PENELITIAN}

Rangkuman data penelitian tersebut dapat dilihat pada Tabel 2 dengan menggunakan analisis deskriptif.

Tabel 2. Rangkuman Data Hasil Perhitungan Analisis Deskriptif.

\begin{tabular}{|c|c|c|c|c|}
\hline \multirow{2}{*}{ Kemampuan Berpikir Kreatif } & \multicolumn{3}{|c|}{ Media Pembelajaran } \\
\cline { 3 - 5 } & iSpring Suite & $\begin{array}{c}\text { Power Point 2013 } \\
\text { (A1) }\end{array}$ & Total \\
\hline Tinggi (B1) & N & 15 & 15 & 30 \\
\hline
\end{tabular}




\begin{tabular}{|c|c|c|c|c|}
\hline \multirow{2}{*}{\multicolumn{2}{|c|}{ Kemampuan Berpikir Kreatif }} & \multicolumn{3}{|c|}{ Media Pembelajaran } \\
\hline & & $\begin{array}{l}\text { iSpring Suite } \\
\text { (A1) }\end{array}$ & $\begin{array}{c}\text { Power Point } 2013 \\
\text { (A2) }\end{array}$ & Total \\
\hline & $\Sigma \mathrm{X}$ & 491 & 407 & 898 \\
\hline & $\Sigma \mathrm{X}^{2}$ & 16117 & 11087 & 27204 \\
\hline & $\bar{X}$ & 32,73 & 27,13 & 59,86 \\
\hline & $\mathrm{S}$ & 1,72 & 1,79 & 3,51 \\
\hline \multirow{5}{*}{ Rendah (B2) } & $\mathrm{N}$ & 15 & 15 & 30 \\
\hline & $\Sigma \mathrm{X}$ & 284 & 310 & 594 \\
\hline & $\Sigma \mathrm{X}^{2}$ & 5436 & 6456 & 11892 \\
\hline & $\bar{X}$ & 18,93 & 20,67 & 39,6 \\
\hline & S & 2,03 & 1,97 & 4 \\
\hline \multirow{5}{*}{ Total } & $\mathrm{N}$ & 30 & 30 & 60 \\
\hline & $\Sigma X$ & 775 & 717 & 1492 \\
\hline & $\Sigma \mathrm{X}^{2}$ & 21553 & 17543 & 39096 \\
\hline & $\bar{X}$ & 51,66 & 47,8 & 99,46 \\
\hline & $S$ & 3,75 & 3,76 & 7,51 \\
\hline
\end{tabular}

Selanjutnya data dideskripsikan atas skor terendah, skor tertinggi, skor rerata dan prosentasenya. Penghitungan median (Me), modus (Mo), dan standar deviasi (Sd) secara keseluruhan dan masing-masing data kelompok. Persyaratan pengujian analisis varians untuk data setiap kelompok telah terpenuhi, yaitu: data setiap kelompok berdistribusi normal, memiliki varians yang homogeny dan dari sampel yang ditentukan secara random. Uji hipotesis dilakukan dengan analisis varians dua jalur faktorial $2 \mathrm{x}$ 2 tentang data hasil belajar Bahasa Indonesia. Hasil analisis data hasil belajar Bahasa Indonesia dengan ANAVA dua jalur faktorial 2 × 2, disajikan pada Tabel 3 .

Tabel 3. Ringkasan Perhitungan ANAVA Faktorial $2 \times 2$

\begin{tabular}{|c|c|c|c|c|c|}
\hline Sumber Varians & Dk & JK & RJK & $F_{\text {hitung }}$ & $\begin{array}{c}F_{\text {tabel }} \\
0,05\end{array}$ \\
\hline Antar Kelompok (A) & 1 & 56,067 & 56,067 & 15,94 & \\
\cline { 1 - 4 } Dalam Kelompok (B) & 1 & 1540,267 & 1540,267 & 437,99 & \multirow{2}{*}{4,01} \\
\hline Interaksi (AxB) & 1 & 201,666 & 201,666 & 57,35 & \\
\hline Galat & 56 & 175,2 & 3,52 & & \\
\hline Total & 59 & 1994,933 & & & \\
\hline
\end{tabular}

Hasil perhitungan yang diterkan pada Tabel 2 menunjukkan bahwa $F_{\text {hitung }}$ sebesar $15,94>\mathrm{F}_{\text {tabel }} 4,01$ dengan taraf signifikansi $\alpha=$ 0,05 . Hal itu dilakukan untuk menguji hipotesis statistik:

$$
\mathrm{H}_{\mathrm{o}}:{ }^{\mu} \mathrm{A}^{1} \leq{ }^{\mu} \mathrm{A}^{2} ; \mathrm{H}_{\mathrm{a}}:{ }^{\mu} \mathrm{A}^{1} \geq^{\mu} \mathrm{A}^{2}
$$

Pernyataan hipotesisnya:

$\mathrm{H}_{0}$ : Hasil belajar Bahasa Indonesia siswa yang menggunakan media pembelajaran interaktif iSpring Suite lebih rendah atau sama dengan hasil belajar Bahasa Indonesia siswa yang menggunakan media pembelajaran microsoft office power point 2013.

$\mathrm{H}_{\mathrm{a}}$ : Hasil belajar Bahasa Indonesia siswa yang menggunakan media pembelajaran interaktif iSpring Suite lebih tinggi atau sama dengan hasil belajar Bahasa Indonesia siswa yang menggunakan media pembelajaran microsoft office power point 2013. Dengan demikian, $\mathrm{H}_{0}$ ditolak dan $\mathrm{H}_{\mathrm{a}}$ diterima.

Hasil belajar Bahasa Indonesia siswa yang menggunakan media pembelajaran 
interaktif iSpring Suite lebih tinggi atau sama dengan hasil belajar Bahasa Indonesia siswa yang menggunakan media pembelajaran microsoft office power point 2013 teruji kebenarannya.

Demikian pula halnya dengan hasil belajar Bahasa Indonesia siswa dengan kemampuan berpikir kreatif tinggi lebih tinggi dibandingkan dengan hasil belajar siswa dengan kemampuan berpikir kreatif rendah. Pada tabel tertera $F_{\text {hitung }} 437,99>F_{\text {tabel }} 4,01$, dengan taraf signifikansi $\alpha=0,05$. Adapun hipotesis penelitian yang diuji adalah

$$
\mathrm{H}_{\mathrm{o}}:{ }^{\mu} \mathrm{B}^{1} \leq{ }^{\mu} \mathrm{B}_{2} ; \quad \mathrm{H}_{\mathrm{a}}:{ }^{\mu} \mathrm{B}^{1} \geq^{\mu} \mathrm{B}_{2}
$$

Pernyataan hipotesisnya:

$\mathrm{H}_{0}$ : Hasil belajar Bahasa Indonesia siswa dengan kemampuan berpikir kreatif tinggi lebih rendah atau sama dengan hasil belajar Bahasa Indonesia siswa dengan kemampuan berpikir kreatif rendah.

$\mathrm{H}_{\mathrm{a}}$ : Hasil belajar Bahasa Indonesia siswa dengan kemampuan berpikir kreatif tinggi lebih tinggi atau sama dengan hasil belajar Bahasa Indonesia siswa dengan kemampuan berpikir kreatif rendah. Dengan demikian $\mathrm{H}_{0}$ ditolak dan $\mathrm{H}_{\mathrm{a}}$ diterima.

Ringkasan ANAVA faktorial 2x2 pada Tabel 2 juga menunjukkan bahwa $F_{\text {hitung }}(57,35)$ $>\mathrm{F}_{\text {tabel }}(4,01)$. Ini berarti $\mathrm{H}_{0}$ ditolak, sebaliknya $\mathrm{H}_{\mathrm{a}}$ diterima pada taraf signifikansi $\alpha=0,05$. Adapun hipotesis yang diuji adalah :

$\mathrm{H}_{\mathrm{o}}$ : Interaksi ${ }^{\mu} \mathrm{A}><\mu_{\mathrm{B}}=0$

$\mathrm{H}_{\mathrm{a}}$ : Interaksi ${ }^{\mu} \mathrm{A}><\mu_{\mathrm{B}} \neq 0$

Dengan demikian, hipotesis penelitian yang menyatakan adanya interaksi antara media pembelajaran interaktif iSpring Suite dan kemampuan berpikir kreatif dalam memengaruhi hasil belajar Bahasa Indonesia teruji kebenarannya.

Sehubungan dengan adanya interaksi, perlu dilakukan uji lanjut dengan uji Scheffe karena adanya perbedaan data pada setiap sel. Hasil pengujian dengan Uji Scheffe, ditampilkan pada Tabel 4, berikut ini.

Tabel 4. Ringkasan Hasil Pengujian dengan Menggunakan Uji Scheffe untuk Setiap Pasangan Hipotesis

\begin{tabular}{|c|c|c|c|c|}
\hline \multicolumn{2}{|c|}{ Hipotesis Statistik } & $F_{\text {hitung }}$ & $F_{\text {tabel }}$ & Keterangan \\
\hline $\mathrm{H}_{0}: \mu \mathrm{A}_{1} \mathrm{~B}_{1} \leq \mu \mathrm{A}_{2} \mathrm{~B}_{1}$ & $\mathrm{H}_{\mathrm{a}}: \mu \mathrm{A}_{1} \mathrm{~B}_{1} \geq \mu \mathrm{A}_{2} \mathrm{~B}_{1}$ & 8,28 & 2,54 & Signifikan \\
\hline $\mathrm{H}_{0}: \mu \mathrm{A}_{1} \mathrm{~B}_{1} \leq \mu \mathrm{A}_{1} \mathrm{~B}_{2}$ & $\mathrm{H}_{\mathrm{a}}: \mu \mathrm{A}_{1} \mathrm{~B}_{1} \geq \mu \mathrm{A}_{1} \mathrm{~B}_{2}$ & 20,40 & 2,54 & Signifikan \\
\hline $\mathrm{H}_{0}: \mu \mathrm{A}_{1} \mathrm{~B}_{1} \leq \mu \mathrm{A}_{2} \mathrm{~B}_{2}$ & $\mathrm{H}_{\mathrm{a}}: \mu \mathrm{A}_{1} \mathrm{~B}_{1} \geq \mu \mathrm{A}_{2} \mathrm{~B}_{2}$ & 17,83 & 2,54 & Signifikan \\
\hline $\mathrm{H}_{0}: \mu \mathrm{A}_{2} \mathrm{~B}_{1} \leq \mu \mathrm{A}_{1} \mathrm{~B}_{2}$ & $\mathrm{H}_{\mathrm{a}}: \mu \mathrm{A}_{2} \mathrm{~B}_{1} \geq \mu \mathrm{A}_{1} \mathrm{~B}_{2}$ & 12,12 & 2,54 & Signifikan \\
\hline $\mathrm{H}_{0}: \mu \mathrm{A}_{2} \mathrm{~B}_{1} \leq \mu \mathrm{A}_{2} \mathrm{~B}_{2}$ & $\mathrm{H}_{\mathrm{a}}: \mu \mathrm{A}_{2} \mathrm{~B}_{1} \geq \mu \mathrm{A}_{2} \mathrm{~B}_{2}$ & 9,55 & 2,54 & Signifikan \\
\hline $\mathrm{H}_{0}: \mu \mathrm{A}_{1} \mathrm{~B}_{2} \leq \mu \mathrm{A}_{2} \mathrm{~B}_{2}$ & $\mathrm{H}_{\mathrm{a}}: \mu \mathrm{A}_{1} \mathrm{~B}_{2} \geq \mu \mathrm{A}_{2} \mathrm{~B}_{2}$ & $-2,57$ & 2,54 & Tidak Signifikan \\
\hline
\end{tabular}

Interaksi antara pembelajaran yang menggunakan media pembelajaran interaktif iSpring Suite dan media pembelajaran microsoft office power point 2013 dengan kemampuan berpikir kreatif tersebut dapat divisualisasikan dalam bentuk grafis pada Gambar 1 berikut ini.

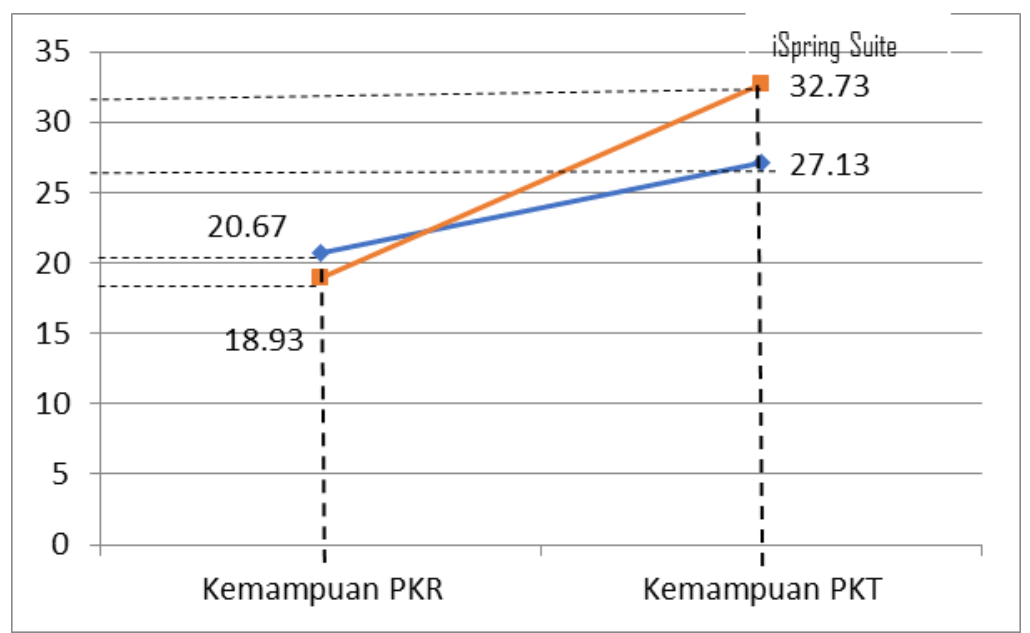

Gambar 1. Interaksi Media Pembelajaran Berbasis Komputer dan kemampuan berpikir kreatif terhadap Hasil Belajar Bahasa Indonesia 


\section{PEMBAHASAN}

Data penelitian menunjukkan bahwa terdapat perbedaan hasil belajar Bahasa Indonesia siswa yang menggunakan media pembelajaran interaktif iSpring Suite dan media pembelajaran microsoft office power point 2013. Hasil belajar Bahasa Indonesia siswa yang pembelajarannya menggunakan media pembelajaran interaktif iSpring Suite lebih tinggi dibandingkan dengan menggunakan media pembelajaran microsoft office power point 2013. Siswa lebih tertarik, termotivasi, dan tertantang dalam melakukan pembelajaran dengan media interaktif iSpring Suite dibandingkan dengan menggunakan media Microsoft Office Power Point 2013 karena media tersebut memuat seluruh materi pada satu jendela dan kuisnya yang bersifat interaktif. Kemudahan memilih materi pada media iSpring Suite yang bersifat audiovisual juga mendukung siswa untuk mengeksplorasi bagian-bagian yang dikehendaki pada jendela iSpring Suite secara luas. Seperti dikemukakan Situmorang dalam Ningsih (2012:3) penggunaan media audiovisual (termasuk di dalamnya media berbasis komputer) dapat memberikan kesempatan yang luas kepada siswa dan guru untuk mengembangkan kemampuannya dalam investigasi dan analisis. Hal tersebut didukung pula oleh pendapat Dale dalam Rusman, dkk (2011:173) yang menyatakan bahwa kurang lebih $90 \%$ hasil belajar seseorang diperoleh melalui indra pandang (visual), 5\% dari indra mendengar (audio), dan 5\% lagi dari indra lainnya.

Hasil penelitian ini juga membuktikan kebenaran pendapat yang dikemukakan Sadiman (2003) bahwa media pembelajaran mendukung kegiatan belajar, di mana fungsi atau kegunaan media antara lain : memungkinkan siswa berinteraksi langsung dengan lingkungannya, membangkitkan motivasi belajar, menyajikan informasi belajar secara konsisten dan dapat diulangi maupun disimpan menurut kebutuhan, menyajikan pesan atau informasi belajar secara serempak, membatasi batasan waktu maupun ruang, dan mengontrol arah maupun kecepatan belajar siswa.

Eksplorasi kemampuan yang dimiliki secara optimal melalui media iSpring Suite dalam pembelajaran memperlihatkan bahwa siswa dengan kemampuan berpikir kreatif tinggi lebih mudah mencapai ketuntasan belajar pada ketiga kompetensi dasar mata pelajaran Bahasa Indonesia yang diteliti pada penelitian ini dibandingkan dengan siswa yang memiliki kemampuan berpikir kreatif rendah. Kesempatan luas dalam berinteraksi dengan lingkungannya (berupa media pembelajaran berbasis komputer) merupakan proses kreatif yang menghasilkan perilaku kreatif bagi siswa yang memiliki kemampuan berpikir kreatif tinggi. Seperti dinyatakan Talajan (2009:63) ...proses kreatif berlangsung sejak dari mulai tumbuh akibat interaksi individu dengan lingkungannya sampai berwujud perilaku kreatif.

Pada penelitian ini, proses pembelajaran Bahasa Indonesia berbasis komputer dilakukan secara individual di laboratorium komputer dengan pengawasan oleh guru mata pelajaran. Siswa diberi kesempatan dan keleluasaan dalam memanfaatkan media komputer (iSpring Suite dan microsoft office power point 2013) sesuai kemampuannya dengan alokasi waktu yang telah ditentukan.

Siswa dengan kemampuan berpikir kreatif tinggi akan lebih mudah dan cepat memahami materi pembelajaran yang disajikan dengan cara belajar interaktif dan mandiri. Kemampuan berpikir kreatif cenderung lebih mudah berkembang jika siswa diberi kesempatan berperan secara aktif dalam mempraktikkan kegiatan-kegiatan pembelajaran. Kemampuan mereka akan semakin tertantang dan tereksplorasi dengan hal-hal yang bersifat "baru" lagi menyenangkan. Mereka menemukan semua itu pada media pembelajaran interaktif iSpring Suite. Praktik langsung akan semakin meningkatkan hasil belajar Bahasa Indonesia siswa yang memiliki kemampuan berpikir kreatif tinggi.

Hasil belajar Bahasa Indonesia siswa dengan kemampuan berpikir kreatif tinggi yang menggunakan media iSpring Suite lebih tinggi daripada hasil belajar Bahasa Indonesia siswa dengan kemampuan berpikir kreatif rendah yang menggunakan media pembelajaran microsoft power point 2013 disebabkan : media iSpring Suite bersifat interaktif sehingga siswa dengan kemampuan berpikir kreatif tinggi merasa lebih tertantang untuk mempelajari materi lebih jauh daripada siswa dengan kemampuan berpikir kreatif rendah yang hanya menggunakan media pembelajaran microsoft 
office power point 2013 yang tidak bersifat interaktif; rasa ingin tahu dan motivasi belajar siswa semakin meningkat karena media pembelajaran interaktif iSpring Suite bukan hanya memuat tulisan (visual) melainkan suara (audio) juga dapat disertakan. Hal ini selaras dengan hasil penelitian Damasari yang menyimpulkan bahwa penggunaan media pembelajaran iSpring Suite dapat meningkatkan motivasi belajar Fisika siswa kelas XI SMA Muhammadiyah 2 Yogyakarta.

Siswa dengan kemampuan berpikir kreatif tinggi cenderung lebih tertantang menggunakan media pembelajaran yang relatif baru daripada siswa dengan kemampuan berpikir kreatif rendah. Media pembelajaran interaktif iSpring Suite bagi siswa kelas V SD Islam Al Ulum Terpadu Medan T.P. 2015/2016 masih relatif baru karena guru kelas atau guru mata pelajaran masih jarang menggunakannya. Sementara itu, media pembelajaran microsoft office power point merupakan media yang sudah biasa mereka lihat pada proses pembelajaran. Oleh karena itu, siswa dengan kemampuan berpikir kreatif rendah yang menggunakan media pembelajaran interaktif iSpring Suite cenderung merespon kurang antusias, mengalami kendala dalam beradaptasi dengan media interaktif iSpring Suite diasumsikan siswa beranggapan bahwa media tersebut semakin menyulitkan proses pembelajaran karena sudah terbiasa hanya pasif mendengarkan atau melihat. Sebaliknya, siswa dengan kemampuan berpikir kreatif tinggi dapat dengan mudah menyesuaikan diri dalam pembelajaran yang menggunakan media iSpring Suite apalagi menggunakan media microsoft office power point 2013.

Mata pelajaran Bahasa Indonesia merupakan mata pelajaran yang melatih dan mengasah kemampuan logika berpikir. Siswa dengan penguasaan bahasa yang baik, cenderung mampu memverbalkan segala sesuatu yang dipikirkan, menuangkan gagasan dalam bentuk-bentuk ujaran atau tulisan verbal. Kemampuan ini akan lebih mudah dikuasai oleh siswa dengan kemampuan berpikir kreatif tinggi daripada siswa dengan kemampuan berpikir kreatif rendah. Kemampuan berpikir kreatif siswa sebanding dengan kemampuan verbalnya. Biasanya siswa dengan kemampuan berpikir kreatif tinggi mampu memproduksi atau mereproduksi ujaran atau tulisan verbal yang variatif. Misalnya, semakin tinggi penguasaan kosakata seorang siswa, akan semakin variatif ujaran atau tulisan verbal yang dihasilkannya berarti pula bahwa kemampuan berpikir kreatif siswa itu pun semakin tinggi.

Dengan menggunakan media
pembelajaran microsoft office power point 2013 yang secara umum menayangkan visual verbal, siswa yang memiliki kemampuan berpikir kreatif tinggi akan lebih mudah memahami dan menuntaskan materi pembelajaran yang dipelajarinya daripada siswa yang memiliki kemampuan berpikir kreatif rendah.

Hasil belajar Bahasa Indonesia siswa dengan kemampuan berpikir kreatif rendah akan lebih baik jika pembelajarannya menggunakan media pembelajaran interaktif iSpring Suite dibandingkan dengan media pembelajaran microsoft power point 2013. Hal ini disebabkan karena siswa akan lebih mudah untuk memahami materi dengan cara melakukan pengulangan dengan pelatihanpelatihan pada materi yang diberikan. Media pembelajaran interaktif $i$ Spring Suite dapat pula digunakan untuk mengulangi bahan pelatihan yang disajikan sehingga dapat menambah kecepatan belajar siswa. Pada umumnya, siswa dengan kemampuan berpikir kreatif rendah yang menggunakan media pembelajaran microsoft power point 2013 kurang bergairah untuk mencoba strategi pembelajaran yang "baru". Mereka akan merasa lebih nyaman dengan strategi pembelajaran yang konvensional. Penggunaan media pembelajaran iSpring Suite dalam pembelajaran lebih mereka sukai daripada media pembelajaran microsoft office power point. Seperti dikemukakan oleh Munawwaroh dalam hasil penelitiannya tentang Pengembangan Media Pembelajaran IPA Berbasis Multimedia Menggunakan Software iSpring Suite 6.2 untuk SD/MI Kelas V Materi Organ Tubuh Manusia dan Fungsinya bahwa $100 \%$ siswa merespon positif penggunaan media pembelajaran iSpring Suite.

\section{PENUTUP}

Berdasarkan hasil penelitian dan pembahasannya yang dikemukakan pada bab IV diperoleh simpulan hasil penelitian, sebagai berikut.

1. Hasil belajar Bahasa Indonesia siswa yang menggunakan media pembelajaran interaktif iSpring Suite lebih tinggi daripada hasil belajar Bahasa Indonesia siswa yang menggunakan media pembelajaran microsoft office power point 2013. 
2. Hasil belajar Bahasa Indonesia siswa dengan kemampuan berpikir kreatif tinggi lebih tinggi daripada hasil belajar Bahasa Indonesia siswa dengan kemampuan berpikir kreatif rendah.

3. Terdapat interaksi antara penggunaan media pembelajaran berbasis komputer dalam pembelajaran dengan kemampuan berpikir kreatif siswa terhadap hasil belajar Bahasa Indonesia. Siswa dengan kemampuan berpikir kreatif tinggi yang menggunakan media pembelajaran interaktif iSpring Suite ataupun microsoft office power point 2013 hasil belajar Bahasa Indonesianya lebih tinggi daripada siswa yang memiliki kemampuan berpikir kreatif rendah.

\section{DAFTAR PUSTAKA}

Ahmadi, Iif Khoiru, dkk. Strategi Pembelajaran Berorientasi KTSP. Jakarta: Prestasi Pustaka Publisher.

Anderson Lorin W dan David R. Krathwohl (eds). 2010. Kerangka Landasan untuk Pembelajaran, Pengajaran, dan Asesmen. Yogyakarta: Pustaka Pelajar.

Asrori, Muhammad. 2009. Psikologi Pembelajaran. Bandung: CV Wacana Prima

Aunurrahman. 2010. Belajar dan Pembelajaran. Bandung: Alfabeta.

BSNP. 2009. Standar Kompetensi dan Kompetensi Dasar SD/MI (Lampiran I Permendiknas No.22 Tahun 2006). Jakarta: Direktorat Pembinaan TK dan SD, Dirjen Dikdasmen Depdiknas.

Darmawan, Deni. 2014. Pengembangan ELearning - Teori dan Desain. Bandung \: PT Remaja Rosdakarya.

Davies, Ivor K. 1991. Pengelolaan Belajar. Terjemahan oleh Sudarsono, dkk. 1991. CV Rajawali: Jakarta.

Depdiknas. 2008. Bahan Ajar Diklat Tingkat Lanjut. Jakarta: Dirjen PMPTK Pusat Pengembangan dan Pemberdayaan Pendidik dan Tenaga Kependidikan Bahasa.

Djamarah, Syaiful Bahri. 2008. Psikologi Belajar Edisi 2. Jakarta: Rineka Cipta.

Driscoll, Marcy P. t.t. Psychology of Learning for Instruction. Boston: Florida State University.

Faturrahman, P., dan Sutikno. 2007. Strategi Belajar Mengajar Melalui Penanaman Konsep Umum Dan Konsep Islami, Bandung : Refika Aditama.
Gagne, R. M. dan M.P. Driscoll. 1989. Essential of Learning Instruction $2^{\text {nd }}$ Edition. Englewood Cliffs, New Jersey: Prentice Hall Inc.

Hanafiah, Nanang dan Cucu Suhana. 2010. Konsep Strategi Pembelajaran. Bandung: PT Refika Aditama.

Jamaris, Martini. 2013. Orientasi Baru dalam Psikologi Pendidikan. Bogor: Ghalia Indonesia.

Kartikasari, Dewi dan Gesang Kristianto Nugroho. 2010. Media Pembelajaran Interaktif Mata Pelajaran Bahasa Jawa Pokok Bahasan Aksara Jawa Pada Sekolah Menengah Pertama Negeri 2 Tawangsari Kabupaten Sukoharjo. Journal Speed-Sentra Penelitian Engineering dan Edukasi, Vol. 2 No.3:16 (Online), (http://ijns.org diakses 12 Desember 2015).

Kementerian Pendidikan dan Kebudayaan. 2012. Standar Kompetensi dan Kompetensi Dasar Sekolah Dasar (Lampiran 1 Permendiknas No. 22 Tahun 2006). Jakarta: Direktorat Pembinaan Sekolah Dasar Dirjen Dikdas.

Kementerian Pendidikan dan Kebudayaan. 2014. Materi Pelatihan Guru Implementasi Kurikulum 2013. Jakarta: BPSDM Dikbud dan Penjaminan Mutu Pendidikan Kemdikbud.

Khodijah, Nyayu. 2014. Psikologi Pendidikan. Jakarta: PT Raja Grafindo Persada.

Kurniawan, Heru. (2014). Pembelajaran Menulis Kreatif -Berbasis Komunikatif dan Apresiatif. Bandung: PT Remaja Rosdakarya.

Kusmayadi, Ismail. 2011. Guru Juga Bisa (Me)Nulis. Bandung: Tinta Emas Publishing.

Miarso, Yusufhadi. 2009. Menyemai Benih Teknologi Pendidikan. Jakarta: Prenada Media Group.

Mularsih, Heni. 2010. Strategi Pembelajaran, Tipe Kepribadian dan Hasil Belajar Bahasa Indonesia Sekolah Menengah Pertama. Makara, Sosial Humaniora, 14(1): 65-74.

Ningsih, Siska Rahayu. 2012. Pengaruh Penggunaan Media Berbasis Komputer (CD Movie dan Flash) terhadap Hasil Belajar Siswa Kelas XI pada Pokok Bahasan Koloid. Makalah Disajikan dalam Seminar Pemenuhan Tugas Produksi Media Pembelajaran Kimia 
Lanjutan, Unimed, Medan. (Online) diakses 12 Desember 2015.

Purwanto, M. Ngalim. 2009. Prinsip-prinsip dan Teknik Evaluasi Pengajaran. Bandung: PT Remaja Rosdakarya.

Pusat Bahasa, Depdiknas. 2000. Kamus Besar Bahasa Indonesia, Edisi Ketiga. Jakarta: Balai Pustaka.

Rusman, dkk.,. 2011. Pembelajaran Berbasis Teknologi Informasi dan Komunikasi: Mengembangkan Profesionalisme Guru. Jakarta: PT Raja Grafindo Persada.

Sabri, Ahmad. 2010. Strategi Belajar Mengajar \& Mico Teaching. Jakarta: Quantum Teaching.

Sadiman, A.S. dkk. 2014. Media Pendidikan: Pengertian Pengembangan, dan Pemanfaatannya. Jakarta: CV. Rajawali.

Sagala, S. 2009. Konsep dan Makna Pembelajaran. Jakarta: Penerbit Alfabeta.

Sanjaya, Wina. 2010. Strategi Pembelajaran Berorientasi Standar Proses Pendidikan. Jakarta: Prenada Media Group.

Setyosari, Punaji. 2010. Metode Penelitian Pendidikan dan Pengembangan. Jakarta: Kencana Pranada Group.

Slameto. 2010. Belajar dan Faktor-faktor yang Mempengaruhi. Jakarta: Rineka Cipta.

Smaldino Sharon E., Deborah and Russel. 2011. Instructional Technology \& Media for Learning Teknologi Pembelajaran dan Media untuk Belajar Edisi Kesembilan. Jakarta: Kencana Prenada Media Group.

Sri Harningsih, Angel Susiana dan Efendi Napitupulu. 2014. Penggunaan Multimedia Pembelajaran Interaktif dan Kreativitas terhadap Hasil Belajar TIK. Teknologi Informasi dan Komunikasi dalam Pendidikan, 1(1):24-37.

Sumiati, dan Asra. 2009. Metode Pembelajaran. Bandung: CV. Wacana Prima.

Suriasumantri, Jujun S. 2005. Filsafat Ilmu: Sebuah Pengantar Populer. Jakarta: Pustaka Sinar Harapan.

Susilana, Rudi dan Riyana, Cepi. 2009. Media Pembelajaran: Hakikat, Pengembangan, Pemanfaatan dan Penilaian. Bandung: CV. Wacana Prima.

Sutikno, M.S. 2009. Belajar dan Pembelajaran. Bandung: Pressport.

Taba, Hilda. 1962. Curriculum Development Theory and Practice. New York,
Chicago, San Fransisco, Atlanta: Harcourt, Brace \& World, Inc.

Talajan, Guntur. 2012. Menumbuhkan Kreativitas dan Prestasi Guru. Yogyakarta: Laksbang Pressindo.

Tarigan, Henry Guntur. 1990. Membaca sebagai Suatu Keterampilan Berbahasa. Bandung: Angkasa.

Tarigan, Henry Guntur. 2000. Menulis sebagai Suatu Keterampilan Berbahasa. Bandung: Angkasa.

Warsita, Bambang. 2008. Teknologi Pembelajaran. Jakarta: Rinekar Cipta.

Zaini, Hisyam dkk. 2007. Strategi Pembelajaran Aktif. Yogyakarta: CTSD (Center for Teaching Staff Development) IAIN Sunan Kalijaga. 